ks. Jan Nowak

\title{
Troska o człowieka: świadectwo i program Jana Pawła II. Refleksja na podstawie książki „,Wstancie, chodźmy!” i encykliki „Redemptor hominis”
}

Tytuł tego artykułu wskazuje na dwa dzieła Ojca Świętego. Świadectwem Jana Pawła II nazwałem wspomnienia z okresu pasterzowania w archidiecezji krakowskiej, które noszą tytuł Wstańcie, chodźmy! Program swojego pontyfikatu Ojciec Święty zawarł w pierwszej encyklice Redemptor hominis ogłoszonej w 1979 roku.

W tym artykule chcę się pochylić nad troską Papieża o człowieka. Refleksja ta jest wyrazem wdzięczności naszego pokolenia za posługę i świadectwo ks. Kardynała. Wspomnienia zawarte we Wstańcie, chodźmy! pomagają zrozumieć biskupa, który służąc Bogu i człowiekowi, ukazał również, jak Bóg przygotowywał go do posługi na Stolicy Piotrowej. Myślę, że nie będzie przesadą twierdzenie, że program encykliki Redemptor hominis rodził się już w Krakowie. „Dla mnie te spotkania [z księżmi] okazały się cenną okazją, by dzięki nim poznawać skarbiec mądrości zgromadzony przez lata apostolskiego trudu"1. W ten sposób przez lata posługi ks. Kardynał czerpał mądrość dla programu swojej pierwszej encykliki i całego pontyfikatu.

Artykuł podzieliłem na trzy części. W pierwszej przywołałem niektóre komentarze do encykliki Redemptor hominis, które zwracały szczególną uwagę na elementy antropologiczne. W drugiej wskazałem na świadectwo, jakie daje Jan Paweł II o Chrystusie, człowieku i Kościele we wspomnieniach Wstańcie, chodźmy! W ostatniej części ukazałem program encykliki Redemptor hominis ze szczególnym uwzględnieniem troski o człowieka.

\section{Komentarze do encykliki Redemptor hominis}

Przed 25 laty Ojciec Święty ogłosił orędzie o Jezusie Chrystusie, Odkupicielu człowieka, w encyklice Redemptor hominis. Encyklika ta stała się przedmiotem wielu komentarzy i dyskusji. Krakowskie środowisko teo-

${ }^{1}$ Jan PaWex II, Wstańcie, chodźmy!, Kraków 2004, s. 66. 
logiczne poświeciło jej w roku 1979 jeden z numerów „Ruchu Biblijnego i Liturgicznego"2. Warto wymienić najważniejsze tematy, jakie komentatorzy podkreślali w swoich opracowaniach.

O roli Pisma Świętego w encyklice napisał w swoim artykule pt. Biblijne podstawy encykliki Jana Pawta II „Redemptor hominis” ks. Jerzy Chmiel. Podkreślił on w sposób jasny główne tematy biblijne, jakie zawiera encyklika, a są to: idea odkupienia, koncepcja historii zbawienia, „metanoia” oraz temat stworzenia człowieka i jego drogi. Te główne tematy stały się ideami przewodnimi następnych encyklik i wielu przemówień papieskich. Autor obliczył także, że Papież użył aż 205 cytatów z Pisma Świętego, podkreślając przez to bogactwo Słowa Bożego rozważonego w encyklice ${ }^{3}$. Ks. Jan Kowalski w swoim artykule Refleksje moralisty na marginesie „Redemptor hominis” podkreślił moralne aspekty encykliki ${ }^{4}$. Ks. Jan Szkodoń w artykule Udziat chrześcijan w potrójnej misji Jezusa Chrystusa wedtug encykliki „Redemptor hominis” przedstawił ukazane w encyklice posłannictwo prorockie, kapłańskie i misję pasterskokrólewską chrześcijanina we współczesnym świecie ${ }^{5}$. Natomiast Duchowość odkupienia środkiem odnowy Kościoła według encykliki „,Redemptor hominis” to temat artykułu ks. Stanisława Nowaka. Autor ukazuje za Janem Pawłem II chrześcijańską miłość, która zrozumiała jest jedynie poprzez ideę powołania poszczególnych chrześcijan i odpowiedzialność za tę łaskę . Wydaje się, że autorzy, ukazując biblijny, moralny i duchowy wymiar encykliki, wskazali na to, że odpowiada ona podstawowym potrzebom współczesnego człowieka, a przez to jest świadectwem i programem pracy dla Kościoła. Podobnym tematom poświęcili swoje komentarze także niewymienieni autorzy.

Na uwage zasługuje podkreślana w późniejszych komentarzach idea osoby ludzkiej i jej niezbywalnych praw. Między innymi s. Zofia Józefa Zdybicka USJK w tekście Personalistyczne podstawy o człowieku zbawionym zwraca uwagę na te tematy ${ }^{7}$. Ks. prof. Tadeusz Styczeń w Mitość a sens życia podkreśla, że dla współczesnego życia źródłem nadziei jest Jezus Chrystus, Odkupiciel człowieka ${ }^{8}$. Do najważniejszych tematów, jakie podkreślają komentatorzy, należy także dodać godność osoby ludzkiej, którą Papież podkreśla i uwypukla idąc za nauką Pisma Świętego i Tradycji chrześcijańskiej9.

2 „Ruch Biblijny i Liturgiczny” 6 (1979).

${ }^{3}$ Por. tamże, s. 297-303.

${ }^{4}$ Por. tamże, s. 336-340.

${ }^{5}$ Por. tamże, s. 341-347.

${ }^{6}$ Por. tamże, s. 347-357.

${ }^{7}$ Por. Jan PaweŁ II, Redemptor hominis. Tekst i komentarze, red. Z. J. Zdybicka, Lublin 1982, s. 112.

${ }^{8}$ Por. tamże, s. 109.

${ }^{9}$ Por. R. KISIEL, Antropologiczne implikacje encyklik Jana Pawła II, Legnica 1998, s. 36. 
W bardzo trafny sposób te komentarze podsumowuje George Weigel: Ogłoszona 1 marca 1979 roku encyklika „Redemptor hominis” [Odkupiciel człowieka] zapoznała czytelników na całym świecie z analizą współczesnej kondycji ludzkiej, którą Karol Wojtyła zajmował się od trzydziestu lat. Miała ona być „wielkim hymnem radości na cześć faktu, że człowiek został odkupiony przez Chrystusa" ${ }^{\prime 10}$.

\section{Świadectwo posługi kard. Karola Wojtyły \\ na stolicy biskupiej w Krakowie}

25 lat po wyborze na Stolicę Piotrową i w 45 lat po otrzymaniu sakry biskupiej Jan Paweł II napisał wspomnienia i refleksje na temat służby Kościołowi krakowskiemu jako jego biskup. Książka Wstańcie, chodźmy! jest nie tylko historyczną relacją o przeszłości, nie brak w niej bowiem wątków teologicznych i antropologicznych. Czytając świadectwo o posłudze na stolicy św. Stanisława wydaje się, że Bóg przygotowywał kard. Karola Wojtyłę do tak odpowiedzialnej posługi w Kościele. Dlatego nie sposób nie doświadczyć w tej książce wizji biskupa jako świadka Chrystusa, człowieka i Kościoła.

\section{Świadek Chrystusa}

Jan Paweł II daje świadectwo o Chrystusie: „Jezus Chrystus to znaczy wierność wezwaniu Ojca, serce otwarte dla każdego spotkanego człowieka, taka wędrówka, że nie ma gdzie «głowy oprzeć» (por. Mt 8, 20), a w końcu Krzyż, a przezeń osiąga się zwycięstwo zmartwychwstania. To właśnie jest Chrystus, Ten, który bez obawy idzie i nie pozwala się zatrzymać, aż się wszystko wypełni, aż wstapi do Ojca swojego i naszego (por. J 20, 17), Ten, który jest ten sam wczoraj $i$ dziś, $i$ na wieki (por. Hbr 13, 8)"'11. Papież jest człowiekiem wiary i w jej świetle patrzy na Kościół, świat i człowieka. Wiara pomaga mu otworzyć serce na Chrystusa i zrozumieć potrzeby współczesnego człowieka. Widzi Chrystusa, który bierze krzyż człowieka i wchodzi z nim w dialog zbawczy. Po to posłał Go Ojciec. Świadectwo takiej wiary daje odwagę, by pójść na spotkanie z Bogiem i wyjść naprzeciw różnorakim potrzebom człowieka. Choćby to spotkanie z człowiekiem było bardzo trudne i wymagało głoszenia trudnej prawdy. „Istotnie nie wolno odwracać się od prawdy, zaprzestać jej głoszenia, ukrywać, nawet, jeśli jest to prawda trudna i jej wyjawienie wiąże się z wielkim bólem. «Poznacie prawdę, a prawda was wyzwoli» (J 8, 32) - oto jest nasze zadanie, a zarazem nasze oparcie!"12. Powyższy fragment wyraża istotę bisku-

\footnotetext{
${ }^{10}$ G. Weigel, Świadek nadziei. Biografia Jana Pawła II, Kraków 2000, s. 368.

${ }^{11}$ JAN PAWEŁ II, Wstańcie, chodźmy!, s. 162.

12 Tamże, s. 147.
} 
piego świadectwa dawanego o Chrystusie i świadectwa wierności człowiekowi, który potrzebuje wyzwolenia z wielorakich uzależnień, konfliktów i poniżania jego godności oraz obrony praw osoby ludzkiej. Takie podejście do człowieka wymagało odkrycia Słowa, które jest wezwaniem, jakie kieruje Chrystus do człowieka. Odkryć prawdę wiary, która mobilizuje do zajęcia się problemem człowieka, a następnie znaleźć osobę, która zajmie się tymi problemami to cel wierności Chrystusowi w duszpasterstwie. „Znalezienie religijnego uzasadnienia dla działania i osoby odpowiedniej do zadań było dobrym początkiem rokującym nadzieję na powodzenie duszpasterskich przedsięwzięć"13. Tak ewangeliczna teza otwiera drogę wiary do człowieka, aby Chrystus rozwiązywał trudności człowieka i zadania duszpasterskie Kościoła.

\section{ŚWIADEK CZŁOWIEKA}

Ks. Kardynał dał świadectwo doskonałego kontaktu z ludźmi. Tak o tych kontaktach pisze: „Jeśli o mnie chodzi, to rzecz znamienna, że nigdy nie miałem wrażenia, żeby liczba moich kontaktów była zbyt duża. Niemniej moją stałą troską było, aby w każdym przypadku zachować indywidualny charakter tych odniesień. Każdy człowiek jest osobnym rozdziałem. [...] Gdy spotykam człowieka, to już się za niego modlę i to zawsze pomaga w kontakcie z nim. [...] Mam taką zasadę, że każdego przyjmuje jako osobę, którą przysyła Chrystus - i jako tego, którego mi dał i zarazem zadał"14. Świadectwo, kim jest dla niego człowiek, jaką wartością i bogactwem, podkreślił szczególnie w pierwszej encyklice, ukazując w niej godność człowieka zakorzenioną w Chrystusie.

Spotkanie z człowiekiem, zwłaszcza cierpiącym, zawsze budowało i wzywało do dzielenia się oraz troski o jego stan wewnętrzny i potrzeby codzienne. „W słabości chorych zawsze dostrzegałem coraz bardziej objawiającą się siłę - siłę miłosierdzia. Chorzy niejako «prowokują» miłosierdzie. Przez swoją modlitwę i ofiarę nie tylko wypraszają miłosierdzie, ale stanowią «przestrzeń miłosierdzia», czy lepiej «otwierają przestrzeń» dla miłosierdzia" 15 . Były to spotkania przygotowujące kard. Wojtyłę do posługi człowiekowi cierpiącemu, który przeżywa ból w wielorakich wymiarach, o czym zaznaczył w Redemptor hominis.

\section{ŚWIADEK KoŚCIOŁa}

Jako biskup czuł się odpowiedzialny za wspólnotę diecezjalną: za świeckich, księży, zakony, dzieci i młodzież. Niemałą uwagę poświęcał głoszeniu słowa Bożego i katechezie. „Katecheza jednak ustawia na pierwszym miejscu

\footnotetext{
${ }^{13}$ Tamże, s. 45.

${ }^{14}$ Tamże, s. 58.

${ }^{15}$ Tamże, s. 65.
} 
człowieka i spotkanie z nim w znakach i symbolach wiary"16. Podkreśla w ten sposób, że katecheza służy człowiekowi i jest znakiem wiary. Rodzi się pytanie: w jaki sposób troska o człowieka ma odniesienie do Boga? Na czym opiera Kościół swoją ewangelizacyjną misję? Beatyfikując matkę Teresę z Kalkuty Papież tak mówił: „Świadectwo życia matki Teresy przypomina wszystkim, że ewangelizacyjna misja Kościoła dokonuje się poprzez miłość, karmiona modlitwą i słuchaniem słowa Bożego. [...] Kontemplacja i działanie, ewangelizacja i promocja człowieczeństwa: matka Teresa głosi Ewangelię swoim życiem w całości ofiarowanym ubogim, a jednocześnie w całości spowitym modlitwą"17. Misja Kościoła dla ks. Kardynała rozpoczyna się od modlitwy. „Zawsze towarzyszyło mi przekonanie, że nie uda nam się wychować dzieci bez modlitwy. Jako biskup starałem się zachęcać rodziny i wspólnoty parafialne, aby wyrabiały w dzieciach pragnienie spotkania z Bogiem na prywatnej modlitwie" ${ }^{18}$. Ważna dla biskupa była troska o dzieci, młodzież i dorosłych, nie tylko o ich modlitwę, ale także o częstą spowiedź i kierownictwo duchowe ${ }^{19}$. Sakramenty, a zwłaszcza Eucharystia, są podstawową służbą Kościoła dla człowieka ${ }^{20}$.

Na czym polega program Jana Pawła II

w encyklice Redemptor hominis?

Zdumiewające jest to, że w pięć miesięcy po inauguracji pontyfikatu Papież ukazuje tak jasny program działania duszpasterskiego aż do roku 2000. Program ten buduje na Chrystusie, Odkupicielu człowieka. Od Chrystusa wszystko się zaczyna. Zaczyna się objawienie miłości Ojca i posłanie uświęcające Ducha Świętego. Chrystus jest ratunkiem dla człowieka i jego niezbywalnych praw. Chrystus w Kościele i przez Kościół naucza i prowadzi do wolności w miłości. Człowiek jest drogą pełnego Bożej miłości Kościoła. W Chrystusie człowiek odnajduje siebie, sens życia i miłość. Dlatego przypatrzmy się zasadniczym myślom programowym encykliki Redemptor hominis. Po 25 latach możemy powiedzieć, że jest to program pełen nadziei. Nadziei dla zmęczonego człowieka. Jest to program Kościoła niosącego nadzieję światu.

\section{„OtwóRzcie dRzwi Chrystusowi!”}

Jan Paweł II dzięki posłuszeństwu wiary wobec Odkupiciela przyjął posługę kierowania Kościołem. Papież daje świadectwo troski Kościoła

\footnotetext{
16 Tamże, s. 85.

${ }^{17}$ Tamże, s. 89.

${ }^{18}$ Tamże, s. 83-84.

${ }^{19}$ Por. tamże.

${ }^{20}$ Por. tamże, s. 60-62.
} 
o człowieka, który zagubiony i zniewolony, szuka Odkupiciela. Objawia On Ojca w Duchu Świętym. Ojcowska miłość miłosierna ukazuje się człowiekowi w Jezusie Chrystusie, po to by odnalazł on swoją godność i na nowo został stworzony przez Ducha. Jan Paweł II zdumiony wartością i godnością człowieka, wzywa go do kontemplacji tajemnicy odkupienia, która dokonała się przez krzyż, śmierć i zmartwychwstanie Chrystusa. Tylko w ten sposób człowiek może się odnaleźć. Wielki szacunek wobec wartości duchowych różnych religii pomaga w Chrystusie odkryć pełną wizję człowieka. Kościół, który ewangelizuje, ukazuje Chrystusa ocalającego godność człowieka. Na spotkanie człowieka zagubionego wychodzi Chrystus i jednoczy się z nim. To zjednoczenie z człowiekiem jest nowym stworzeniem, odkupieniem i uszczęśliwieniem. Ojciec Święty przypomina o tym współczesnemu światu w encyklice, gdyż takie dziedzictwo i świadectwo otrzymał po wielkich papieżach Janie XXIII i Pawle VI. Oni bowiem wskazali w swoich encyklikach na godność człowieka oraz na rolę Kościoła we współczesnym świecie, który prowadzi człowieka do Chrystusa.

\section{NADZIEJA DLA CZŁOWIEKA}

Papież wraz z całym Kościołem daje świadectwo, że Chrystus przyszedł, aby życie człowieka uczynić bardziej ludzkim. Dlatego troska Kościoła obejmuje życie całego człowieka, jego własną historię, jego potrzeby egzystencjalne, jego więzi społeczne i rodzinne. Podstawową prawdą encykliki są słowa: „człowiek jest pierwszą i podstawową drogą Kościoła”21. Człowieka rozdartego przez grzech, a jednocześnie dążącego do prawdy, sprawiedliwości i miłości chce światu ukazać Kościół. Może to czynić, bo człowieka mocą śmierci i zmartwychwstania Chrystusa jednoczy z Ojcem i przez Ducha udziela mu mocy do wypełnienia jego powołania.

Biblijny obraz bogacza i Łazarza staje się realny współcześnie. Ukazuje on, że żadne struktury społeczne nie potrafią zmienić tej dysproporcji, jaka istnieje między bogatymi a biednymi. Mało tego, często pogłębiają one tę dysproporcję i powiększają obszar nędzy, doprowadzając często do rozpaczy i frustracji. Inflacja i bezrobocie to objawy tego nieładu moralnego. Potrzebna jest więc przemiana serc i umysłów, aby struktury oparte na ładzie moralnym pomogły pokonać te nierówności i nędzę. W przeciwnym razie postęp ekonomiczny zawładnie całą egzystencją, zdusi człowieka i całe życie społeczne. W myśl ewangelicznego obrazu Sądu Ostatecznego trzeba podjąć rachunek sumienia, czy zamiast chleba nie dajemy broni, czy nie zamieniamy budżetów ekonomicznych w budżety militarne.

${ }^{21}$ JAN PAWEe II, enc. Redemptor hominis, 14. 
W imię kochającego Boga Kościół wzywa do obrony życia, wolności i godności człowieka. Jednak na drodze do tego celu człowiek napotyka na niebezpieczeństwa. Coraz bardziej lęka się owocu swojej pracy, który może go zniszczyć. Niekontrolowany rozwój techniki, rozwój militarny, eksploatacja surowców ziemi zagraża środowisku naturalnemu. Człowieka czyni egoistą szukającego doraźnego użycia i panowania.

Papież zadaje patynie: Czy przez postęp człowiek staje się lepszy, duchowo dojrzalszy, świadomy swojej godności, odpowiedzialny, otwarty na drugich, zwłaszcza słabszych? Czy pomiędzy narodami i wspólnotami rośnie sprawiedliwość i miłość społeczna? Czy rozwój materialny nie służy panowaniu nad bliźnimi? Być czy mieć? Jeżeli zwycięża mieć, człowiek staje się niewolnikiem produkcji i techniki, zatraca, kim naprawdę jest, a dynamizm życia codziennego daleki jest od obiektywnych wymagań moralnych. Ta postawa doprowadza do tego, że społeczeństwo staje się konsumpcyjne, a świat dzieli się na bogatych i głodujących.

Wiek XX, wiek zniszczeń, krzywd i cierpień potrzebuje pokoju, który jest dziełem sprawiedliwości i poszanowania nienaruszalnych praw człowieka. Jeśli nie ma takiej dążności, mamy do czynienia z terroryzmem, mordami i dyskryminacją. Dobro człowieka i dobro wspólne służy wychowaniu i poszanowaniu nienaruszalnych, obiektywnych praw człowieka, szczególnie prawa do wolności religijnej i wolności sumienia. Często ateizm ma takie prawa, że traktuje wierzących jako ludzi drugiej kategorii lub tylko toleruje. Wierzącemu nie są potrzebne przywileje, ale poszanowanie elementarnych praw. Szacunek dla człowieka i jego praw staje się początkiem przemiany świata w bardziej sprawiedliwy i wolny, a przez to bardziej ludzki.

\section{MisJa KoŚcioŁA}

Wszystko, co o sytuacji człowieka zostało powiedziane, „skierowuje nasze myśli i serca ku Jezusowi Chrystusowi. Ku tajemnicy odkupienia, w której sprawa człowieka wpisana jest ze szczególną mocą w prawdę i miłość"22. Tajemnica zjednoczenia Chrystusa z człowiekiem jest ukazana w Kościele i w ten sposób doczesność przeżywana jest w perspektywie życia wiecznego. Synostwo Boże, którym jest obdarzony człowiek, wskazuje na wymiar duchowy, bo pochodzi ono od Ojca przez Syna w Duchu Świętym. Dlatego każdy chrześcijanin ma udział w potrójnym posłannictwie: prorockim, kapłańskim i królewskim.

Za misję prorocką odpowiedzialne jest magisterium Kościoła, a więc biskupi, kapłani, a za jej wypełnianie w świecie także katecheci. Jan Paweł II podkreśla, że cała praca katechetyczna zaczyna się od katechezy rodzi-

\footnotetext{
22 Tamże, 18.
} 
ców. W ten sposób nie tylko biskupi i kapłani, ale i świeccy mają udział w posłannictwie prorockim Chrystusa ze względu na chrzest.

Posługa kapłańska, której udziela Chrystus, dając swoją zbawczą moc, wyraża się zwłaszcza w Eucharystii i w pokucie. I to jest najważniejsze świadectwo dla współczesnego świata. Sakrament Eucharystii zawiera tajemnicę zjednoczenia człowieka z Bogiem. Najświętszy Sakrament jest prawdą o tym zjednoczeniu i w ten sposób Eucharystia buduje jedność i wspólnotę Kościoła. Kościół żyje Eucharystią przez to, że rozwija ducha modlitwy, braterstwa, ducha zaufania. W sakramencie pokuty Kościół przyjmuje człowieka grzesznego, jego ducha pokuty i żalu oraz chęć jego przemiany. W tym sakramencie udziela przebaczenia przez Chrystusa Odkupiciela, pojednując z Ojcem.

Powołaniem każdego chrześcijanina jest świadectwo służby i królowania, widać to przede wszystkim w wierności, którą mają się odznaczać małżonkowie, kapłani, siostry zakonne. Papież podkreśla ponadto wartość służby, oddania i miłości apostolskiej. Kościół potrzebuje Matki - Matki Kościoła. Jej macierzyński charyzmat jest potrzebny, bo w ten sposób otacza szczególną miłością człowieka, jest Ona obecna na drogach codzienności. Encyklika przygotowuje na Jubileusz dwu tysiąclecia Zbawienia. Przygotowuje programem i modlitwą. „Ufam, że przez taką modlitwę otrzymamy zstępującego na nas Ducha Świętego i staniemy się świadkami Chrystusa aż po krańce ziemi”"23.

Podsumowując, warto podkreślić, że po 26 latach od wydania encykliki jest ona nadal aktualna, a przez wspomnienia zawarte w książce Wstańcie, chodźmy! bardziej jeszcze nam bliska. Dziękując Ojcu Świętemu za to świadectwo, czujemy się zobowiązani do podjęcia w jeszcze większym stopniu dzieła troski o człowieka. Program wyrażony w encyklice nie stracił nic z aktualności. Wydaje się tylko, że człowiek dojrzał do tego programu i bardziej go potrzebuje. Trzeba, aby to świadectwo papieskie rozważył jeszcze raz, ciągle je rozważał i wprowadzał w życie.

Kraków

KS. JAN NOWAK

\section{Zusammenfassung}

Die Sorge um den Menschen: Das Zeugnis und das Programm von Johannes Paulus dem II. Ein Nachdenken über das päpstliche Buch „Steht auf, lasset uns gehen!“ und über die Enzyklika Redemptor hominis

Das Zeugnis des Papstes Johannes Paulus II. über die von ihm geschenkte Menschensorge, ruft uns zu besonderer Neigung und dem Nachdenken über das Gott- und Menschengeheimnis und das Begegnungsmysterium mit Christus in der Kirche. Die Grundreflexion

${ }^{23}$ Tamże, 22. 
darüber machen die zwei im Titel erwähnten Werke des Heiligen Vaters aus: "Steht auf, lasst uns gehen!“ und die Enzyklika Redemptor hominis.

Die Botschaft über Jesus Christus, den Erlöser des Menschen, die infolge der Enzyklika Redemptor hominis vor den 25 Jahren die Welt umgekreist hat, ruf eine sehr lebendige Resonanz in vielen theologischen Milieus auf. Es wurden die wichtigsten Denken und Ideen der Enzyklika unterschrieben und kommentiert.

Jesus Christus, der Erlöser des Menschen, ist der Grundschlüssel zum Verständnis des vom Johannes Paulus II. in der Enzyklika Redemptor hominis angegebenen Programms. Der Papst ruft: „Öffnet Christus die Tür!”. Nur Er ist die eine und einzige Hoffnung des Menschen. Deshalb hat die Kirche die wesentliche Aufgabe, diese Wahrheit zu verkünden und dem Menschen in seiner Begegnung mit Christus zu helfen.

25 Jahre nach seiner Papstwahl hat der Heilige Vater im Buch „Steht auf, lasst uns gehen!“ wesentliche Erinnerungen und Reflexionen über seinen bischöflichen Dienst in Krakau enthält. Man kann dieses Nachdenken in drei Schichten vorstellen: der Christus-, Menschen-und Kirchenzeuge. 


\title{
ZAPRASZAMY
}

na konferencję naukową Polskiego Towarzystwa Teologicznego

\section{DZIEDZICTWO POLSKICH ŚWIETYCH PRZELOMU XIX I XX WIEKU \\ Modele świętości prezentowane przez wyniesionych na ołtarze przez Jana Pawła II polskich świętych i błogosławionych}

\author{
Instytut Jana Pawła II w Krakowie (ul. Kanonicza 18) \\ czwartek, 10 listopada 2005, godz. 9.00
}

\begin{abstract}
TEMATY
Troska Ojca Świętego Jana Pawła II o beatyfikacje i kanonizacje polskich świętych • Wzorce ideowe biskupów polskich wyniesionych do chwały ołtarzy przez Jana Pawła II (bł. Michał Kozal, bł. Jerzy Matulewicz, św. Józef Sebastian Pelczar, bł. Józef Bilczewski, bł. Zygmunt Szczęsny Feliński) • Męczennicy polscy wyniesieni do chwały ołtarzy przez Jana Pawła II i ich przesłanie (bł. Stefan Wincenty Frelichowski, bł. Karolina Kózkówna, bł. Michał Kozal, bł. 11 sióstr nazaretanek z Nowogródka, św. Jan Sarkander, św. Melchior Grodziecki, św. Maksymilian M. Kolbe, bł. 108 męczenników z lat II wojny światowej; bł. Wincenty Lewoniuk i 12 towarzyszy) • Wzorce ideowe władców polskich wyniesionych do chwały ołtarzy przez Jana Pawła II (św. Jadwiga Król Polski, św. Kinga) - Kapłani i zakonnicy wyniesieni do chwały ołtarzy przez Jana Pawła II i ich przesłanie dla współczesnych (bł. Honorat Koźmiński, bł. Franciszka Siedliska, św. Adam Chmielowski, św. Rafał Kalinowski, św. Jan z Dukli, bł. Maria Angela Truszkowska, bł. Regina Protmann, bł. Bolesława Lament, bł. Rafał Chyliński, bł. Stanisław Kaźmierczyk, bł. 11 sióstr nazaretanek z Nowogródka, św. Maksymilian M. Kolbe, bł. Kolumba Gabriel, bł. Sancja Szymkowiak, bł. Marcelina Darowska, bł. Maria Karłowska, bł. Bernardyna M. Jabłońska, wybrane osoby z lat bł. 108 męczenników z lat II wojny światowej, św. Faustyna Kowalska, św. Urszula Ledóchowska, bł. Jan Beyzym oraz kapłani: bł. Stefan Winceny Frelichowski, św. Jan Sarkander, św. Melchior Grodziecki, bł. Zygmunt Gorazdowski, bł. Jan Balicki) • Zakonodawcy wyniesieni do chwały ołtarzy przez Jana Pawła II i ich przesłanie (bł. Edmund Bojanowski, bł. Jerzy Matulewicz, bł. Honorat Koźmiński, bł. Franciszka Siedliska, św. Adam Chmielowski, bł. Maria Angela Truszkowska, bł. Regina Protmann, bł. Bolesława Lament, bł. Kolumba Gabriel, bł. Marcelina Darowska, bł. Maria Karłowska, bł. Bernardyna M. Jabłońska, św. Faustyna Kowalska, św. Urszula Ledóchowska) • Zesłańcy i inni patrioci polscy wyniesieni do chwały ołtarzy przez Jana Pawła II i ich przesłanie dla współczesnych (św. Adam Chmielowski, św. Rafał Kalinowski, bł. 11 sióstr nazaretanek z Nowogródka, bł. 108 męczenników z lat II wojny światowej, bł. Zygmunt Szczęsny Feliński, bł. Wincenty Lewoniuk i 12 towarzyszy) • Wzorce ideowe osób świeckich wyniesionych do chwały ołtarzy przez Jana Pawła II (bł. Edmund Bojanowski, bł. Karolina Kózkówna, bł. Aniela Salawa, św. Jadwiga Król Polski, wybrane osoby spośród grona 108 męczenników z lat II wojny światowej, św. Kinga, bł. Wincenty Lewoniuk i 12 towarzyszy).
\end{abstract}

\section{PRELEGENCI}

bp dr Jan Szkodoń (biskup pomocniczy archidiecezji krakowskiej) • ks. prof. dr hab. Jan Dyduch (rektor Papieskiej Akademii Teologicznej w Krakowie) • ks. prof. dr hab. Marian Wolicki (dziekan Wydziału Zamiejscowego Nauk o Społeczeństwie KUL w Stalowej Woli) • ks. prof. dr hab. Kazimierz Panuśs (prezes Polskiego Towarzystwa Teologicznego) • ks. dr hab. Roman Królikowski (Kielce) • 0. prof. PAT dr hab. Józef Marecki OFMCap. (wiceprezes Polskiego Towarzystwa Teologicznego) • ks. prof. PAT dr hab. Jacek Urban (dyrektor Instytutu Jana Pawła II w Krakowie) 